\title{
Balkanologie
}

Balkanologie Revue d'études pluridisciplinaires

Vol. VI, $n^{\circ}$ 1-2 | 2002

Volume VI Numéro 1-2

\section{From Foe to Friend and back}

Albanians in Serbian History Textbooks 1918-2000

De l'ennemi à l'ami, et inversement. Les Albanais dans les manuels d'histoire serbes, $1918-2000$

\section{Zoran Janjetović}

\section{OpenEdition}

\section{Journals}

\section{Electronic version}

URL: http://journals.openedition.org/balkanologie/460

DOI: 10.4000/balkanologie.460

ISSN: 1965-0582

Publisher

Association française d'études sur les Balkans (Afebalk)

\section{Printed version}

Date of publication: 1 December 2002

Number of pages: $245-260$

ISSN: 1279-7952

Electronic reference

Zoran Janjetović, « From Foe to Friend and back», Balkanologie [Online], Vol. VI, n 1-2 | 2002, Online since 04 February 2009, connection on 17 December 2020. URL : http://journals.openedition.org/ balkanologie/460 ; DOI : https://doi.org/10.4000/balkanologie.460 


\section{FROM FOE TO FRIEND AND BACK ALBANIANS IN SERBIAN HISTORY TEXTBOOKS 1918-2000}

Zoran Janjetović*

The Serbs and the Albanians were neighbours presumably ever since the arrival of the Slavs on the Balkan Peninsula. However, for quite a long time the Albanians were the Serbs' least important neighbours. It was only in the last 120-odd years that their importance for the Serbs, and accordingly for the Serbian historiography, started to increase gradually. It would be closer to the truth if we said that in the past five or so years the Albanians became the most important Serbian neighbours. Unfortunately, that was due to confrontation rather than cooperation. However, that was not always the case in the more distant past. In this paper the author proposes to investigate which moments from the shared, or purely Albanian history are to be found in Serbian history textbooks, to analyze how they are described and how the changes in the Serbian Albanian policy and mutual relations were reflected in schoolbooks.

\section{ANCIENT TIMES AND MIDDLE AGES}

When one deals with the Serbian-Albanian relations, the first question that comes to mind is when did the common history actually begin ? The Albanians claim that they are the direct descendants of the Illyrians who were inhabiting a large portion of the Balkan Peninsula in the ancient times ${ }^{1}$. This

- Assistant, Institut za noviju istoriju Srbije (Institute for more recent history of Serbia), Belgrade.

${ }^{1}$ Anamali (Skender), “ Des Illyriens aux Albanais ", Studia albanica, (2), 1972, pp. 153-171; Pollo (Stefanaq), Puto (Arben), eds., Histoire de l'Albanie des origines à nos jours, Roanne, 1974, pp. 36-40; Les Illyriens et la genèse des Albanais, Tirana, 1971. 
view is not always endorsed by Serbian scholars ${ }^{2}$. As usual, the dispute is not purely an academic one. The opposing parties often try to legitimate their claims to certain territories by asserting prior habitation whether this is historically correct or not. In the case of the Serbs and Albanians, the bone of contention is Kosovo. Therefore, at first sight it may seem paradoxical that practically in all Serbian schoolbooks dealing with the Balkans in the ancient times and/or at the time of the settlement of the Slavs in the $7^{\text {th }}$ century, the Illyrians are mentioned as direct ancestors of the present-day Albanians. However, there is no contradiction. Although not all Serbian archeologists and historians dealing with the subject approve of this thesis, it was possible for the textbook authors to concede partly to the Albanian view because they never claimed that the Illyrians were transformed into Albanians on the whole territory presently inhabited by the Albanians. Indeed, as we shall presently see, they view the appearance of the Albanians in Kosovo and adjacent territories in quite different light than their Albanian colleagues who claim that the Albanians are autochtonous on all the territories they inhabit today.

Writing about the Middle Ages, Serbian textbooks seldom mention the Albanians. As a rule conquests of the Serbian kings in Albania are mentioned. Only sometimes is the actual role of the Albanians briefly mentioned. A schoolbook from early fifties reports about the clashes between the Slavic newcomers and the indigenous population, without mentioning the Albanians by name 3 . A textbook from the Milošević era states that there were frictions in those parts where the South Slavs lived intermingled with the non-Slavs, but other numerous ties were also mentioned, even if only in passing 4 . In some textbooks the resistance of the Albanians to the invasion by the emperor Dušan is mentioned5, while their collaboration with him in war against the Byzantine Empire is mentioned in one schoolbook from the socialist period ${ }^{6}$. It is by no means a coincidence that the schoolbooks published before the Second World War when there was no love lost between Yugoslavia and Albania, and when the conditions of

\footnotetext{
${ }^{2}$ Garašanin (Milutin), Illyrians and Albanians in Kosovo. Past and Present, Belgrade : s.a., pp. 33-38 ; Garašanin (Milutin), "Nastanak i poreklo Ilira ", in : Garašanin (Milutin), ed., Iliri i Albanci. Serija predavanja održanih od 26. maja do 4. juna 1986. godine, Beograd, 1988, p. 76 ; Jovanović (Slobodan), " Jugosloveni i Albanci ", Ideje, 5-6, 1987, p. 181.

3 Čubrilović (Ljubica) et al., Istorija. Udžbenik za četvrti razred osnovne škole, Beograd, 1959 (6th edition), p. 100.

4 Ćirković (Sima M.), Istorija za drugi razred gimnazije prirodno-matematičkog smera, Beograd, 1997 (5th edition), p. 62.

5 Prica (Dušan M.), Istorija jugoslovenskog naroda (Srba, Hrvata, Slovenaca) za treći razred osnovne škole, Beograd, 1933 (3rd edition), p. 28 ; Perović (Rade M.), Vojinović (Siniša), Zemljopis sa istorijom za prvi razred stručnih produžnih škola, Skopje, 1939 (5th edition), p. 53.
}

${ }^{6}$ Božić (Ivan), Pregled istorije od XI do XIX veka za drugi razred gimnazije prirodno-matematičkog smera, Beograd, 1963, p. 48. 
the Albanian minority in Yugoslavia were anything but good, emphasized confrontation. On the other hand, since the communist authorities after the Second World War went out of their way to satisfy the legitimate needs of the national minorities, a post-war textbook puts emphasis on cooperation between the Serbian emperor and the Albanians. Surprisingly enough, despite their general tendency, not even the schoolbooks from this period mention many dynastic ties, cultural interlocking and mutual assimilation in the adjacent areas.

Curiously, Dušan's imperialism at the Albanians' expense is condemned in some of the pre-war textbooks, but not in the Marxist ones as one would expect. However, there is no incongruency in this : the authors who decry Dušan's conquests do it from a nationalist point of view, i.e. because the emperor was not building up a national state but was simply collecting foreign lands under his sway?.

The only other way the Albanians are mentioned in Serbin textbooks dealing with the Middle Ages is as shepherds in medieval Serbia. The development of the Albanian culture in that period ${ }^{8}$ is mentioned in only one textbook from the late 1980 s, and there is only one other where something about the medieval Albanian history in general could be found 9 . All this fits into the general pattern of neglecting the non-Slavic neighbours (and indeed some Slavic ones too !) in Serbian history textbooks.

\section{EARLY MODERN TIMES}

The Albanians are somewhat more often mentioned in the context of the struggle of the Balkan peoples against the Ottoman invasion in the $14^{\text {th }}$ and $15^{\text {th }}$ centuries. The mention of the famous Albanian leader Skender-bey (George Kastriot) is made in some, but by no means in all textbooks dealing with the period ${ }^{10}$. Three out of four of these textbooks were published in comparatively more recent times when some more attention was paid to the nonSlavic neighbours in Serbian textbooks. The remaining one, dating from the 1930 , as if to offset the too positive impression the reader might get, claims

\footnotetext{
7 Vuković (Danilo), Opšta istorija srednjeg veka za šesti razred srednjih škola, Beograd 1938, p. 117 ; Vuković (Danilo), Djerić (Miloš), Opšta istorija srednjeg veka za više razrede srednjih $i$ stručnih škola, Beograd, 1931 (5th edition), pp. 123-124.

${ }^{8}$ One quarter of the page is devoted to the subject : kulturološko-jezičke, pravno-birotehničke, prosvetne $i$ dramske, Beograd, 1988 (2nd edition), p. 111.

9 Ćirković (Sima M.), op. cit., pp. 63-64 ; Mihaljčić (Rade), Istorija za šesti razred osnovne škole, Beograd, 1999 (gth edition), pp. 86-89.

${ }^{10}$ Ibid., p. 65 ; Mihaljčić (Rade), op. cit., p. 87 ; Božić (Ivan), Istorija za šesti razred osnovne škole, Beograd, 1979 (2nd edition), p. 137 ; Vuković (Danilo), op. cit., p. 134.
} 
that since the fall under the Ottoman rule the Albanians became the "most loyal sons of the Sultan"11. Apart from this, next to nothing can be read in Serbian schoolbooks about the Albanians under the Ottoman rule until the end of the $17^{\text {th }}$ century.

Thus we come to probably the most disputed juncture in the SerbianAlbanian history. It is the great Viennese War (1683-1699) and the so-called Great Migration of the Serbs (from Kosovo and Serbia to Southern Hungary, i.e. the present-day Vojvodina). After lifting the siege of Vienna, the Austrian troops penetrated as deep into the Ottoman territory as Kosovo and Northern Macedonia. On their way they were joined by Serbian and Albanian Christians who, at first, greeted them as liberators. However the participation of the Albanians, although a well established fact ${ }^{12}$, is never mentioned in Serbian textbooks. When the tide turned, the Serbs (and some Albanians) had to flee before the revengeful Turks. Thus, according to the more traditionalist and/or nationalistic Serbian historiography, Kosovo became to a large degree depopulated, which enabled the Albanians, who had been only a tiny minority there before, to settle down and oust or assimilate a great part of the remaining $\mathrm{Serbs}^{13}$. In schoolbooks this version can be found in six of the books from before and four from after the Second World War. It is clear that the theme occurs more often in older textbooks, sometimes recounted in quite ghastly terms ${ }^{14}$; however, although the process of Albanian settlement was much longer and much more complicated, not even Marxist textbook authors were able to resist the well established over-simplified historiographical tradition, even though they speak of the events without the bloodthirsty flourish of the pre-war nationalists. It is really surprising that a textbook from the Miloševic era for the third year of secondary school does not mention the Albanian influx ${ }^{15}$. The important episode is also omitted from several textbooks from the socialist period, presumably for reasons mentioned above or for simple lack of space.

\footnotetext{
${ }^{11}$ Vuković (Danilo), ibid.

${ }^{12}$ Kostić (Mita), " Prilozi istoriji srpsko-arbanskog ustanka " 1689-169o, Arhiv za arbansku starinu, jezik i etnologiju, 2, 1924-1925, pp. 12-20 ; Malcolm (Noel), Kosovo. A Short History, London, 1998, pp. 144-150.

${ }^{13}$ Kosovo i Metohija u srpskoj istoriji, Beograd 1989, pp. 140-14 ; Bogdanović (Dimitrije), Knjiga o Kosovu, Beograd, 1985, p. 80 . On the other hand, some Albanian authors play down the significance of the migration, or deny it altogether. Rizaj (Skender), " Sur le prétendu grand exode serbe du Kosovo avec à sa tête le patriarche Arsenije Čarnojević (169o) ", Studia Albanica, (1), 1984, pp. 83-107.

14 Thus Dj. Lazarevic writes : " These new inhabitants of our southerm parts tore down many churches and monasteries and other monuments of our medieval past ". (Lazarević (Djordje B.), Istorija za četvrti razred gradjanskih škola, Beograd, 1937, p. 42). D. Prica wrote for his part : " The colonized Albanians tormented our people who remained there [i.e. in Kosovo], destroyed churches and monasteries, forcing them [i.e. our people] to renounce their religion and robbing them of their possessions ". (Prica (Dušan M.), Istorija jugoslovenskog naroda (Srba, Hrvata, Slovenaca) za četvrti razred osnovnih škola, Beograd, 1940, p. 95).
}

15 Perović (Milutin), Novaković (Relja), Istorija za treći razred gimnazija opšteg tipa i društveno-jezičkog smera i treći razred stručnih škola, Beograd, 1995 ( $4^{\text {th }}$ edition), p. 98. 


\section{THE AGE OF NATIONALISM}

The Great Migration of the Serbs occurred at the moment that could be seen as a transition from pre-national to national consciousness among the peoples of South-Eastern Europe. The conflicts would assume increasingly national characteristics. The conditions under which the Serbs and Albanians lived within the Ottoman Empire offered an abundance of opportunities for conflicts rather than for cooperation. In the remainder of this paper we shall examine how the conflicting positions of the two ethnic groups within the Ottoman state and society during the $18^{\text {th }}$ and $19^{\text {th }}$ centuries, as well as in the $20^{\text {th }}$ century when the tables were turned, were dealt with in Serbian textbooks.

Writing about the last two centuries of the Ottoman rule most of the Serbian textbooks do not mention the Albanians at all. Sometimes Albanian beys and chieftains are mentioned as the mainstay of the Ottoman Empire in the Balkans ${ }^{16}$. The textbooks from the Milošević era enlarge on the Albanian crimes against the Kosovo Serbs, especially during the $19^{\text {th }}$ century ${ }^{17}$.

On the other hand, the fate of the Muslim population of Serbia, Albanians among them, too, which was expelled, exterminated or forcibly converted to Christianity during the First Serbian Uprising against the Turks (1804-1813), is never mentioned in Serbian textbooks ${ }^{18}$ although they write at great length and with good reason, about the all-important "Serbian revolution" (as it was called by Leopold Ranke). Only the confiscated property of these Muslims is sometimes cursorily mentioned. Thus the students are prevented from realizing that even such epoch-making events are not untainted, i.e. that even peoples fighting for their liberty are not immune from doing injustice ${ }^{19}$.

A similar topic could be found in textbooks when it comes to their coverage of the anti-Turkish wars of 1876-1878 which also triggered off migrations

16 Ibid., p. 190.

${ }^{17}$ Ibid., p. 170 ; Gaćeša (Nikola) et al., Istorija za treći razred gimnazije prirodno-matematičkog smera $i$ četvrti razred gimnazije opšteg i društveno-jezičkog smera, Beograd, 1999 (7th edition), pp. 90-91; Gaćeša (Nikola) et al., Istorija za osmi razred osnovne škole, Beograd, 1993, pp. 47-48. (In the last mentioned one can read : "The Turkish government was tolerant for centuries toward Albanian banditry, robbery and terror in the territories inhabited by the Serbs. That is the way of ousting the Serbs from Kosovo and Metohija, and of usurping their land ". All this is put into the context of the Albanian national awakening, but not of the general anarchy obtaining in the region through larger part of the century).

18 The sole exception to the rule being curt mention that " the Turks " were "expelled $n$ in : Perovic (Milutin), Strugar (Milo), Istorija za sedmi razred osnovne škole, Beograd, 1992, p. 102.

19 These events were not given the due attention even by serious Serbian scholarship, remaining thus white spots of the Serbian historiography too. (Rare exceptions see in : Stojančević (Vladislav), "Politički uzroci promena stanovništva Beograda u vreme Prvog srpskog ustanka ", Godišnjak grada Beograda, (20), 1970, p. 91 ; Janković (Dragoslav), Srpska država prvog ustanka, Beograd, 1984, pp. 66-67, 181). 
on a large scale. The Muslim (predominantly Albanian) population fled or was expelled from the territories liberated by Serbian and Montenegrin armies. However, although these wars are regularly mentioned in all schoolbooks dealing with the period, absolutely none of them makes mention of the expulsion of the Albanians. The case was similar to the one of the First Serbian Uprising, only expulsions of 1878 had more far-reaching consequences : the embittered Albanians were usually settled down in Kosovo, terrorizing the local Serbs, instigating them to flee to free Serbia and upsetting thus the ethnic balance still further ${ }^{20}$. Without knowing these facts, students cannot understand the subsequent bad relations between the two peoples. In this way Serbian students are lulled into believing that their people always fought not only for the just cause, but also always with just means.

Closely connected with the wars of $1876-1878$ is the beginning of the Albanian national awakening embodied in the League of Prizren which was set up by Albanian leaders in 1878 in order to prevent carving up of the Albanian-inhabited territories by victorious Serbia and Montenegro. At the same time, the League laid a claim to autonomy of all Albanian-inhabited parts of the Ottoman Empire, even though the Albanians were only a minority in much of the territory they claimed for themselves. Its importance for the further development of the Albanian national consciousness cannot be overestimated and yet it is mentioned only three times in Serbian textbooks : once in a textbook from 1970s and twice in $198 \mathrm{os}^{21}$. The opinions of Serbian and Albanian historians on the League are diametrically opposed, but in Serbian schoolbooks of the socialist period it was described (because it strove for autonomy) as partly "progressive", and partly as "reactionary" (because it was led by the beys, because it also claimed predominantly non-Albanian territories, and because of its distinctly Muslim character). Small wonder that it was never mentioned in the textbooks published before the Second World War which served the purpose of glorifying everything Yugoslav and neglecting or even denigrating all things foreign, and especially belonging to "unfriendly" nations ${ }^{22}$.

${ }^{20}$ Bogdanović (Dimitrije), op. cit., pp. 137-139 ; Bataković (Dušan T.), " Osnove arbanaške prevlasti na Kosovu i Metohiji 1878 "; Bataković (Dušan T.), Kosovo i Metohija u srpskoj istoriji, p. 217 ; Malcolm (Noel), op. cit., p. 215 ; Pllana (Emin), " Les raisons et la manière de l'exode des refugiés albanais du territoire du sandjak de Nish au Kosovo (1877-1878) n, Studia albanica, (1), 1985, pp. 185-200.

\footnotetext{
${ }^{21}$ Milosavljević (Petar), Dragutinović (Miodrag), Istorija za prvi razred stručnih škola, Beograd, 1974 (2nd edition), pp. 204-205; Knežević (Djordje) et al., Istorija sa elementima istorijskog atlasa za drugi razred usmerenog obrazovanja, Beograd, 1986 (5th edition), p. 43 ; Djuranović (Šarlota), Istorija za drugi razred zajedničkog srednjeg vaspitanja i obrazovanja, Novi Sad, 1986 (7th edition), pp. 99-100.

${ }^{22}$ Rosandić (Ružica), " Patriotsko vaspitanje u osnovnoškolskim udžbenicima ", in Rosandić (Ružica), Pešić (Vesna), eds., Ratništvo, patriotizam, patrijarhalnost. Analiza udżbenika za osnovne škole, Beograd, 1994, p. 44.
} 


\section{THE BALKAN WARS AND THE FIRST WORLD WAR}

The next more close contact of the Serbs and Albanians occurred during the First Balkan War that ended the centuries old Ottoman rule in South-East Europe. Serbia, Montenegro, Greece and Bulgaria routed the Turks, whereas the Albanians, making the best of the bad bargain, proclaimed independence of Albania. Because of the colossal importance of the event, and since Serbia was one of the victors, the war always has an important place in Serbian schoolbooks. Serbian occupation of North Albania is also always mentioned, albeit not under that name. The textbooks from the inter-war period either do not explain the purpose of this action at all, or they exonerate it with economic and strategic reasons which led the Serb politicians to undertake it in the first place. They never question the fact that Serbia had no ethnic, nor even historical reason for occupying those parts.

The textbooks from the socialist period also speak about the occupation condemning it as imperialistic encroachment on Albanian lands by the Serbian bourgeoisie. The contemporary leader of the Serbian social-democrats, Dimitrije Tucovic, who opposed the occupation, is extolled as an example of how the social-democrats (who are always seen as the communists' direct ancestors) held correct views on the nationality issue, that were, of course, inherited by the communists. As usual, the textbooks of this period tend to see everything through a Marxist filter and to explain inter-ethnic conflicts only in terms of class struggle. This approach enabled them to encourage what in the times of socialism used to be called "brotherhood and unity" [of the peoples living in Yugoslavia]. Although this intention of the communist regime was laudable enough, mystifying and simplifying of ethnic problems proved counterproductive in the long run. It prevented students from learning the truth and thus from coming to terms with past conflicts.

During the Milošević era, when the ethnic Albanians became the bêtesnoires of the regime, another mystification, worse still, was at work. Sometimes distortions acquire grotesque proportions. Thus the students can read in one of the textbooks that it was the Serbian and allied troops who liberated Albania ${ }^{23}$ !

There is one lurid aspect of the First Balkan War that is never mentioned in Serbian textbooks. That is Serbian war crimes against the Albanians. The atrocities were at first begun by the Montenegrins, but soon Serbian troops joined in. Although the number of victims is not precisely known to this day, the

\footnotetext{
${ }^{23}$ Gaćeša (Nikola) et al., Istorija za treći razred gimnazije (op. cit.), p. 91. For the schoolbooks from 199os, see : Stojanović (Dubravka), “ Udžbenici kao ogledalo vremena ", in Rosandić (Ružica), Pešić (Vesna), eds., op. cit., pp. 92-93.
} 
fact that massacres occurred is undisputed ${ }^{24}$. However, in order not to taint the heroic picture of the Serbian soldiers, their atrocities are never mentioned in Serbian schoolbooks. Yet, it is only fair to state that, until the Milošević era, in Serbian textbooks of the pre-war, or socialist periods the Albanian atrocities committed against the Kosovo Serbs in the decades preceding the First Balkan War, although well documented as well ${ }^{25}$, were never mentioned. The communist regime was passing over ethnic violence no matter who the perpetrators had been.

However, the authors of the Milošević era (who proved their mettle already under the communist regime!) were no longer squeamish when it came to calling a spade a spade, albeit only in the case of the Albanians. Their approach was still Marxist in the beginning when they tried to distinguish between the "good" and "bad" Albanians on the basis of their class origin ${ }^{26}$. A bit later, as the relations with the ethnic Albanians became completely spoiled, the textbook authors dropped the finesse, condemning the Albanians as a body ${ }^{27}$. The students were informed of the previous Albanian misdeeds, but were spared the knowledge of what could be seen as the Serbian retaliation. They were simply presented with a distorted and one-sided image of the "good guys" (i.e. "us") suffering at the hands of the "bad guys" (i.e. "them"). This pattern was put forward by the regime which found its reason for being in confronting neighbours.

The next important conflict in the history of the Serbian-Albanian relations came about only a few years later, in the winter of 1915-1916, as the Serbian army and a large number of civilians were retreating through the snow-covered mountains of North Albania before the advancing troops of Austria-Hungary, Germany and Bulgaria. On their way they were occasionally attacked by the Albanian mountaineers who were opposed to the Serbian protégé Esad-pasha Toptani. They appear in several, but by no means all textbooks

\footnotetext{
24 Enquête dans les Balkans. Rapport présenté aux directeurs de la dotation par les membres de la commission d'enquête, Paris 1914, passim; Skopiansky (M. D.), Les atrocités serbes d'après les témoignages américains, anglais, français, italiens, russes, serbes, suisses etc., Lausanne, 1919, passim. (The latter work, serving propaganda purposes, should be taken carefully.)
}

25 Bataković (Dušan T.), op. cit., passim ; Rakić (Milan), Konzulska pisma 1905-1911, Beograd, 1985, passim ; Rakić (Milan), Kosovo i Metohija u srpskoj istoriji, pp. 224-243, 260-272, 277 ; Rakić (Milan), Prepiska o arbanskim nasiljima u Staroj Srbiji 1888-1889, Beograd, 1899.

${ }^{26}$ Perović (Milutin), Smiljević (Bogdan), Istorija za prvi razred usmerenog obrazovanja za sve struke, p. 188.

27 Gaćeša (Nikola) et al., Istorija za treći razred gimnazije prirodno-matematičkog smera, Beograd, 1999, 7 th edition, pp. 89-9o ; Gaćeša (Nikola) et al., Istorija za osmi razred osnovne škole, Beograd, 1993, pp. 24, 47. 
of the inter-war period, as "savage Albanians"28. The fact that many textbooks of the period do not mention the episode, testifies to its relative unimportance. The previous Serbian military intervention in favour of Esad-pasha, as well as the assistance of his men rendered during the Serbian retreat of 1915-1916 are never mentioned in Serbian textbooks, preventing thus the students from realizing the great complexity of the situation.

Expectedly, the attacks were never mentioned in the communist schoolbooks. As reasons for hardships of the Serbian army and refugees, cold, hunger and hard terrain are invoked, whereas ambushes on the part of some Albanians are completely omitted. Although the antipathy between Tito's Yugoslavia and Enver Hoxha's Albania was mutual and cordial, the textbook authors (and their task masters) did not want to denigrate part of a people also inhabiting a part of Yugoslavia.

This circumspection was dropped by the schoolbook authors of the Milošević era. The Albanians play their role in the episode again, although they are no longer "savage". Now they are correctly described as opponents of Esad-pasha Toptani, who is succinctly described as "Serbian ally"29. Unfortunately, the briefness which the episode is dealt with does not give enough information to prevent animosity against the Albanians in general.

\section{THE ETHNIC ALBANIANS IN YUGOSLAVIA}

After the First World War the Kingdom of the Serbs, Croats and Slovenes (in 1929 renamed Yugoslavia) was created. It perceived itself as a nation state on the Western European model, but it was in practice as multi-national as the defunct Habsburg Monarchy which it succeeded. National minorities comprised some $12 \%$ of the population and the Albanians were among the most numerous ones. Despite this, Serbian textbooks of the inter-war period ignore as a rule the very existence of national minorities. They sing praises to the Southern Slavs and Slavs in general, taking notice only of the greatest European nations too important to be overseen ${ }^{30}$.

${ }^{28}$ The image of the "savage Albanians" was not particular to the Serbs of those times, although with other authors it did not serve a propaganda purpose. See : Weigand (Gustav), Die Aromunen I, Leipzig, 1895, p. VII ; Smith (G. B), Outlines of European History 1789-1922, London, 1928, p. 95 ; Brailsford (H. N.), Macedonia. Its Races and their Future, London, 1906, pp. 228, 239, 258, 278, 258.

29 Gaćeša (Nikola) et al., Istroija za treći razred gimnazije prirodno-matematičkog smera (op. cit.), p. 114 ; Gaćeša (Nikola) et al., Istorija za osmi razred osnovne škole (op. cit.), p. 65.

${ }^{3 \circ}$ Rosandić (Ružica), art. cit., p. 44. 
Surprisingly enough, national minorities are not a stock in trade of the communist textbooks either. They are mentioned only sporadically and incidentally in the context of the unsolved "national question" in the Yugoslavia of 1918-1941. However, even in this context their role is of secondary importance : the main narrative usually revolves around the unsolved national question of the non-Serb Slavic peoples inhabiting the country. National minorities are depicted as oppressed, just like all other non-Serb peoples ${ }^{31}$. Historical and other reasons for oppression are never provided. The ethnic Albanians were mentioned by name only once. Although their position was hard enough, the author, an orthodox Marxist, exaggerates in her description in order to drive home the point of how terrible the old bourgeois regime had been : " Policy of protracted terror, and even of physical extermination, was applied against the Albanians ${ }^{32}$. Such writing was in full accordance with the then policy of giving the Albanians equal treatment like that enjoyed by the Serbs, or (through positive discrimination) even better, so as to make up for neglecting them in the past 33 .

In the textbooks from the Milošević era national minorities are mentioned only twice, but the ethnic Albanians are not named. In one of the schoolbooks, the authors falsely claim that the rights of national minorities were guaranteed by law (which was not true), implying thus that their position was satisfactory (which it was not) ${ }^{34}$. The regime wanted the same to be believed about the conditions of national minorities, and particularly of the ethnic Albanians, during the 1990 s. In that way schoolchildren learning history were subject to the same kind of manipulation the broad public was subject to in respect the conditions of the minorities in Milošević's Serbia.

Unsatisfactory, and at times really hard position of the ethnic Albanians in the inter-war Yugoslavia spurred them to join German and Italian invaders when the country was attacked by the Axis powers and their satellites in April 1941. The ethnic Albanians, apart from few exceptions, not only sided with the enemy, but remained loyal to him until the end of the Second World War. Looking back, it was very tricky for the communist regime to put a nice face on a nasty affair in schoolbooks which taught history in accordance with the canons of the class struggle and "brotherhood and unity". How did they get out of the quandary?

${ }^{31}$ Grubač (Djordje), Istorija sa osnovima socijalističkog samoupravljanja za osmi razred osnovne škole, Beograd, 1981 (8th edition), p. 74 ; Djuranović (Šarlota), art. cit., pp. 201, 225, 235 ; Knežević (Djordje) et al., Istorija sa elementima istorijskog atlasa za drugi razred usmerenog obrazovanja, Beograd, 1986 (5th edition), p. 81.

\footnotetext{
$3^{2}$ Djuranović (S̆arlota), op. cit., p. 225.

33 Rosandić (Ružica), op. cit., p. 44.

34 Gaćeša (Nikola) et al., Istorija za osmi razred, p. 89.
} 
Two solutions to the problem were found. In one version the number of the ethnic Albanians collaborating with the invaders was strongly diminished, so as to create the impression that they were only exceptions 35 . The other version went like this : due to their low educational level and the hard conditions they had experienced in the inter-war Yugoslavia, the national minorities, in particular the ethnic Albanian masses, were prone to buy the enemy propaganda ${ }^{36}$.

All textbooks from the socialist period mention the participation of national minorities in the partisan movement. Sometimes, it is mentioned only cursorily in order to illustrate how widely accepted was the national policy of the Communist Party which led the movement. In other cases the authors enlarge on the subject magnifying out of all proportion what in fact was only a minor role that the minorities played within the partisan army. The ethnic Albanians are probably the best case in point. Since the partisan movement was, for various reasons, predominantly Serb, until the forced recruitment in the autumn of 1944, the Albanian participation in the "People's Liberation Struggle" (as it was called by the communists) was rather a token one. Textbook writers (writing for the regime which tried to keep the balance among the Yugoslav peoples and national minorities - in good and evil alike) had to stretch this unpleasant historical fact and to convince students that the ethnic Albanians also had made a considerable contribution to the victory of the right cause. Sometimes, they really had to act like spin-doctors. At first sight, the most convincing method was heaping up the names of various ethnic Albanian units 37 . Uninformed students could hardly realize that all these units (indeed like many others) were in fact much smaller than it could have been inferred on the basis of their official military designation. Although some of them featured as battalions or brigades, they in fact comprised only a few dozen soldiers. Sometimes despite this window-dressing the cat was involuntarily let out of the bag. Thus a textbook from 1960 s estimates that there had been some 11000 partisans in Kosovo at the end of 1944, stating that some 4000 of them

\footnotetext{
35 Novaković (Relja), Knežević (Djordje), Istorija za treći razred gimnazije prirodno-matematičkog smera, Beograd, 1962, p. 191 ; Grubač (Djordje), Istorija sa osnovama socijalističkog samoupravljanja za osmi razred osnovne škole, Beograd, 1981 (8th edition), p. 108.

${ }^{36}$ Knežević (Djordje), Smiljvić (Bogdan), Istorija najnovijeg doba za četvrti razred gimnazije (XX vek), Beograd, 1966 (4th edition), pp. 109, 135 ; Knežević (Djordje), Smiljvić (Bogdan), , Istorija sa društvenim urejdenjem za drugi razred stručnih škola, Beograd, 1974, p. 87. (The authors write about Albanian gangs terrorizing the Serbs, but they conclude : " The bulk of the Albanian nationality [i.e. national minority] did not take part in these actions, and for this reason there were no actions of intimidation and large massacres in Kosovo and Macedonia in which the members of the Albanian nationality participated n).

37 Grubač (Djordje), Istorija sa osnovama socijalističkog samoupravljanja, Beograd, 1981 (8th edition), p. 108 ; Novaković (Relja), Nešić (Jovan), Istorija za prvi razred stručnih škola, Beograd, 1966 (4th edition), p. 87 .
} 
had been ethnic Albanians ${ }^{38}$. If one compares this number to the total of almost 500000 Ethnic Albanians in Yugoslavia at that time, it is clear that the Albanians participating voluntarily in the partisan movement were rather an exception. However, because the students were neither acquainted with the number of the ethnic Albanians then living in the country, nor with the fact that they formed $2 / 3$ of the Kosovo population, they were quite misled by the numbers provided.

The textbooks of the Milošević era reverted to historical fact that the bulk of the ethnic Albanians collaborated with the Germans and Italians, but the reasons for such massive high-treason are not explained. Authors make much of the collaboration, persecution of the Serbs and (as yet unidentified number) of illegal immigrants from Albania, but they never seek the reasons for such behaviour in the treatment the Albanian minority during the inter-war period and earlier animosities. A pupil can therefore only conclude that the ethnic Albanians were really bad people to treat their Serbian neighbours that cruelly. In accordance with the nationalist policy of the regime, the textbook authors' task masters wanted to suggest a logical conclusion that if the ethnic Albanians had been so wicked fifty years ago, they could not be any better today. Coupled with the presentation of the post-war behaviour of the ethnic Albanians (to be discussed presently), such writing had the task of putting the ethnic Albanians in bad light and preparing students for regarding them as enemies 39 .

The distortion of historical truth in the socialist period served the purpose of pushing under the carpet ethnic conflicts which occurred during the Second World War. By glossing over, or soft-pedaling ethnic tensions in the past, the policy-makers wanted to prevent ethnic strife in the future. On the other hand, the textbooks from the Milošević era played up the Albanian war crimes in order to make Albanians odious to the Serbian students.

This tendency is continued in the textbooks of the same period in respect to the time after the Second World War. Whereas the schoolbooks from the socialist period, steeped in an apotheosis of the socialist system and its communist leaders, do not mention national minorities, the textbooks from the Milošević era devote considerable space to one of them : the ethnic Albanians. The reason is not their numerical superiority over all other national minorities in Yugoslavia after the end of the Second World War, but the protracted conflict with the ethnic Albanians culminating in the open warfare in 1998-1999.

${ }^{8}$ Novaković (Relja), Nešić (Jovan), op.cit., p. 87.

39 Stojanović (Dubravka), op. cit., p. 77 . 
There are several topics concerning the Albanian minority that did not appear in the schoolbooks from the previous period, but are dealt with in the latest Serbian textbooks. One of them, belonging in fact to the Second World War topics that could have been touched upon but was regularly omitted, is the Albanian rebellion against the new regime in late 1944 and early 1945 that had to be crushed with considerable deployment of partisan forces. The episode is skirted in only two textbooks from the socialist period, it is bashfully described as a fight against the retreating German forces and (in one of the two) the remnants of the Albanian collaborators $4^{\circ}$. In a high-school textbook of the Miloševic era, the rebellion is depicted in detail after stating that the majority of the ethnic Albanians had fought against the partisans and that the rebellion was aided by the German secret service ${ }^{41}$. The purpose of this detailed description (which lacks a historical explanation) is clear in the conclusion of the section : " The obsession with Greater Albania, created in the minds of the separatists and enemies of Yugoslavia lives on $n^{42}$. The subsequent no less uncritical text about Albanian separatism in the after-war period serves to complete the picture of the Albanians as natural foes of the Serbs and Yugoslavia.

As a rule, the textbooks from the socialist period describe the history of Yugoslavia until early fifties, devoting much more space to the make-up of the political system and constitution and their changes (always seen as improvements) than to factual political or social history. Nothing can be found about the national minorities in them. Indeed, citizens as such are totally neglected and sections about the times after the Second World War read like eulogy of Tito, the Communist Party and their wise policy seasoned with Marxist mumbo-jumbo Yugoslav style. Small wonder that the Ethnic-Albanian citizens are also completely absent from those pages.

The ethnic Albanians reappear in the books from the Miloševic era which pay much attention to the times after the Second World War. The development of Yugoslavia in that period is depicted in keeping with tenets of the official doctrine of the Miloševic regime : Serbia and the Serbs were allegedly suppressed and neglected by (a Croat) Tito and his cronies who deprived Serbia of her two autonomous provinces (Kosovo and the Vojvodina) and favored the ethnic Albanians at the expense of the Kosovo Serbs 43 . The passing of the new Yugoslav constitution which granted Kosovo a substantial autonomy in 1974 is

40 Knežević (Djordje), Smiljvić (Bogdan), Istorija najnovijeg doba (op. cit.), p. 166 ; Novaković (Relja), Nešić (Jovan), Istorija za treći razred gimnazije prirodno-matematičkog smera, Beograd, 1962, p. 225.

${ }^{11}$ Gaćeša (Nikola) et al., Istorija za treći razred prirodno-matematičkog smera $i$ četvrtog razreda gimnazije opšteg $i$ društveno-jezičkog smera, p. 185.

42 Ibid.

43 Stojanović (Dubravka), op. cit., pp. 99-100. Such representations are also to be found in geography schoolbooks, as well as in natural history and social sciences books for lower forms. 
seen as the birth-date of the latest wave of Albanian separatism. Oppression of the Serbs and the spread of separatist ideology are described at great length. Although many of the presented facts are true, just like the events of the Second World War, they are quoted without any kind of explanation or additional information. The students are not told about the earlier Kosovo policy of the communist rulers, whereas the historical, social, economic and other reasons which encouraged Albanian separatism are completely ignored. Thus the schoolchildren are not able to realize that Albanian nationalism was nothing very original, and that in fact sooner or later it will have found its opposite numbers among all other peoples living in the former Yugoslavia, and from pretty similar reasons too 44 . Needless to say, the errors of the Milošević regime which led to the flare-up of Albanian nationalism (as well as of all others) are not mentioned. All the blame was put on the previous communist regime and measures of the Milošević regime are one-sidedly depicted as putting right the past wrongs 45 . Just like the adult media consumers in Serbia, students could not understand that by introducing constitutional changes Milošević was not only rectifying some really illogical and in the last resort nefarious institutions, but was also stepping on too many toes in the process. Of course, the regime wanted people to have such warped picture of the latest Serbian and Yugoslav history since it was bent on confrontation and not ironing out ethnic conflicts by reasonable compromise.

\section{CONCLUSION}

The Albanians in Serbian textbook were never much of a topic. Like other national minorities and other non-Slavic neighbours, they have always been more or less neglected. Their image in textbooks varied over time, always within the limit of the contemporary political correctness. The schoolbooks published before the Second World War ignored them to the greatest degree. Those from the communist period also mentioned them only superficially : from the lessons or parts of them devoted to the Albanians, students could not have acquired knowledge either of the Serbian-Albanian relations, or Albanian history proper. When the Albanians do appear on the textbook pages, information about them are usually scant and sketchy. When writing about their history in the $20^{\text {th }}$ century, textbook authors of the socialist era avoid junctures of conflict with the Serbs, or are playing them down in order

44 This certainly does not mean that the Albanian nationalism was the oldest in Yugoslavia ; it was only the first to start the last surge of ethnic tensions which eventually caused the break-up of the state.

45 Stojanović (Dubravka), op. cit., pp. 100-101. 
not to disturb the atmosphere of "brotherhood and unity" preached by the communist regime. During the rule of Milošević, the Albanians were given more space in Serbian schoolbooks than ever before. However, now they appear almost exclusively as bad guys persecuting the Serbs throughout the last 500 years, this being in keeping with the collision course Miloševic pursued in his policy toward the Albanians. At the same time, schoolbooks from all three periods keep mum about the miseries inflicted on the Albanians by the Serbs in the course of the turbulent common history, the sole exception being the condemnation of the Serbian occupation of Northern Albania in 1912-1913 in the textbooks of the socialist period. Because of this Serbian students were never enabled to learn the whole of the mutual history with all its ups and downs. This ignorance was later on not dispersed but rather fortified by media, politicians, publicist and some historians, especially in the inter-war period and in the last fifteen or so years. It is very doubtful if the Marxist distortion of history in schoolbooks had produced the desired effect, especially since other sources of information did much to distort the historical truth in quite the opposite direction. Thus the image of the Albanians as eternal enemies of the Serbs was transmitted to too many Serbian generations. Such history teaching coupled with other means of propaganda, economic decline, political oppression and, last but not least, nationalism on the part of Albanians themselves, breeds armed conflict and the lack of will for reconciliation prevailing today. However, without true knowledge of the common history, with all its dark sides, there can be no reconciliation. Among many other gigantic tasks awaiting the democratic Serbian government, the task of detailed revision of the curricula and the textbooks which should enable students to learn the truth about their own nation and neighbouring peoples and to apply their knowledge critically, is looming large. This task also calls for the new textbook writers who should try to undo what their predecessors who served with equal complaisance the communists and Milošević, have spoiled. This process begun bashfully only last year.

Finally, we should examine to what degree the schoolbooks discussed above corresponded to official curricula and what degree of liberty the schoolbook authors had.

In the Yugoslavia of 1918-1941, the main goal of education (which was the monopoly of the state) was bringing children up to be loyal citizens of the Kingdom. That meant that curricula stressed the national component : everything was subject to nationalistic criteria so as to educate the young in accordance with tenets of the official ideology of "national unity" 46 . Although the Yugoslav state of

${ }^{46}$ Dimić (Ljubodrag), Kulturna politika u Kraljevini Jugoslaviji 1918-1941, Vol. I, Beograd, 1996, pp. 88, 118, 233, 262-263 ; Vol. II, pp. 123, 124, 135, 138, 138, 139, 140, 154, 224 ; Mayer (Martin), Elementarbildung in Jugoslawien (1918-1941). Ein Beitrag zur gesellschaftlichen Modernisierung, München, 1995, pp. 60, 123. 
that period never managed to form a consistent educational policy 47 , it never departed form these basic principles which were reflected in the curricula.

As for the curricula, only three of them were made for all schools : in 1926, revised in 1927 , and a new one in $1936^{64}$. Before that, history teaching was directed by various ad hoc ordinances of the school authorities. As a rule, the history curricula were sketchy, usually given through lesson titles and few curt catchphrases, or, as often as not, names of important Serbian and Yugoslav rulers. The aim was to extol the struggle of the Yugoslavs for freedom and unity, depicted through several striking episodes. The Albanians were not mentioned, so the authors had the liberty to mention them or to leave them out. However, when they did decide to mention them, they were fully conscious what was politically correct and in what way the Albanians were to be mentioned.

After the Second World War, the new communist authorities did their best to win over the national minorities and to gloss over conflicts among the peoples living in the country. Over time the curricula in the post-war Yugoslavia tended to be more detailed, although their basic tenets - loyalty to the communist system and "brotherhood and unity" of the peoples inhabiting the country remained a constant 49 . The latter principle was coined with the aim of diminishing or obliterating completely the past frictions by depicting common historical destiny and struggle for freedom and socialism. It can be observed that the national minorities gained space in curricula (and therefore in schoolbooks) over time ${ }^{50}$. Now the more detailed curricula left the authors little room for creativity. Just like their pre-war colleagues, they were bound by ideological (now Marxist) considerations and demands of political correctness.

This was continued during the Milošević era : the authors of the curricula were often the old ones from the socialist period, and so were the schoolbook writers. They blended in a curious way elements of the old Marxist dogma with the new, nationalist one. In other words, the authors of history schoolbooks followed closely the changes in the official policy. This policy always had its Albanian aspect, and although its importance varied, it did not remain secret to the schoolbook writers. They acted always within the limits of the politically correct and desirable. The fact that often the very same people who had preached "brotherhood and unity" in their texts under Tito, started preaching Serbian nationalism under Milošević, testifies to their low morality. Unfortunately, media and other social factors did little to rectify the distorted historical pictures that were instilled into young minds.

47 Mayer (Martin), op. cit., p. 69 ; Dimić (Ljubodrag), op. cit. (vol. 1, p. 214).

$4^{8}$ Dimić (Ljubodrag), op. cit., p. 121 ; Mayer (Martin), op. cit., p. 73.

49 Rosandić (Ružica), Pešić (Vesna), art. cit.

50 The curricula were published in the official Prosvetni glasnik. 